\title{
Effects of oil pollution on the development of sex cells in sea urchins
}

\author{
M. A. Vashchenko \\ Laboratory of Gametogenesis, Institute of Marine Biology, Far East Science Center, \\ Academy of Sciences of the USSR; Vladivostok 690022, USSR
}

\begin{abstract}
The sea urchin Strongylocentrotus nudus is highly sensitive to oil pollution. Experiments were performed in winter, spring and summer over periods of 15 to 45 days. Experimental urchins were kept in water with hydrocarbon concentrations of 10 to $30 \mathrm{mg} \mathrm{l}^{-1}$, and control urchins in pure sea water. Thermal stimulation by Evdokimov's method was applied to obtain mature sexual products during winter and spring tests. Summer investigations were conducted at temperatures of 17 to $18{ }^{\circ} \mathrm{C}$. The gonads were studied histologically and morphometrically, and the sexual cells obtained were analyzed at the embryological level. No histological and morphometrical differences were recorded between sexual cells of controls and experimentals. However, marked hydrocarbon effects were observed in the embryonic development of artificially fertilized cells from experimental urchins. Control embryos developed normally. Embryogenesis of artificially fertilized gametes from control females and experimental males, and vice versa, was found to be distinctly abnormal. Many abnormalities were identified at the first cleavage stage, as well as in blastula, gastrula and pluteus. Fertilization of experimental eggs with experimental sperm resulted in serious disturbances of embryos, followed by the development of non-viable larvae. On the whole, embryogenesis of sexual cells from experimental urchins was characterized by prominent delay, asynchronism and presence of abnormal non-viable larvae. Consequently, long-term effects of sublethal hydrocarbon concentrations resulted in the formation of defective sex cells and high larval mortality.
\end{abstract}

\section{INTRODUCTION}

Oil pollution has stimulated biologists to investigate the effects of oil, its derivatives and dispersants on marine organisms; this has resulted in a large number of publications devoted to oil pollution. However, as pointed out by Moore \& Dwyert (1974) and Anderson (1977), most papers deal with studies on survival of different animals exposed to high concentrations of hydrocarbons, i. e. with experiments under extreme conditions. Deplorably few data are available on the long-term influence of low concentrations of oil products on life processes, and little is known about the effects of pollution on reproduction, growth and development of marine organisms.

Gametes, embryos and larvae of sea urchins are highly sensitive to oil pollution. The present paper investigates chronic effects of sublethal doses of low hydrocarbon concentrations on sex cells of the sea urchin Strongylocentrotus nudus. The effects of oil on this species have been studied by North et al. (1965), Allen (1971) and Lönning \& Hagström (1975). 


\section{MATERIALS AND METHODS}

Water-soluble fractions of a light diesel fuel " $\mathrm{L}$ " with hydrocarbon concentrations of $30 \pm 5 \mathrm{mg} \mathrm{l}^{-1}$ were used as test substances. The first experiment was conducted from April to May 1978, the second from May to June 1979; each lasted 45 days.

The sea urchins were kept in aerated aquaria. Control urchins lived in pure sea water without oil products. In the first experiment, temperature was elevated from 9 to $17^{\circ} \mathrm{C}$ by Evdokimov's method (1973) of thermal stimulation in order to obtain mature sexual products. In the second experiment, temperature was changed from 10 to $18{ }^{\circ} \mathrm{C}$ in accordance with the annual natural increase in sea-water temperature.

Gonads from 3 groups of sea urchins, initial (taken prior to the experiment), control and experimental, were studied histologically, histochemically and morphometrically. Four variants of embryological experiments were carried out. In the first variant, we used eggs and sperm of the control group; in the second, eggs of controls and sperm of experimentals; in the third, experimental eggs and control sperm; in the fourth, gametes of experimental sea urchins. Fertilization was accomplished in Petri dishes containing $80 \mathrm{ml}$ of pure sea water.

Embryonic development was observed over 3 days. Percentage of normal embryos was estimated $5 \mathrm{~min}$ after insemination and at the first cleavage $(1.5 \mathrm{~h}$ after insemination); in each case 500 embryos were used. The embryos were further inspected at the gastrula and pluteus stages ( 20 and $48 \mathrm{~h}$ after insemination, respectively).

\section{RESULTS AND DISCUSSION}

No histological changes in sex cells of Strongylocentrotus nudus exposed to longterm effects of hydrocarbons were recorded. In controls and experimentals, gametogenesis proceeded normally. Prior to experiments the female acini contained mainly nursery ovocytes; the male acini, spermatogonia and spermatocytes. At the end of the tests, control and experimental gonads contained considerable amounts of mature sex cells. The volumes of acini and ovocytes in gonads from controls and experimentals revealed no morphological differences. Histochemical methods also gave no evidence of differences in contents and distribution of carbohydrates, phospholipids, neutral lipids and RNA in sex cells of controls and experimentals.

The lack of histological disturbances in gonads of sea urchins exposed to long-term effects of sublethal hydrocarbon concentrations was not unexpected. Payne et al. (1978) reported that a 6-month influence of oil on fish did not induce any histological changes in the testes. No histological disturbances were observed in Haliotis sp. and Mytilus californianus inhabiting the zone of natural oil discharge (Straughan, 1976). Reynard (1973) investigated the reproductive potential of female limpets in marine environments polluted with the wastes of an oil refinery by measuring the gonad index. He did not observe any damaging effect of hydrocarbons on production of eggs by Patella vulgata. No papers came to our attention on histochemical studies of animal sex cells affected by hydrocarbons.

In spite of the absence of morphological disturbances, embryological investigations showed that the sex cells of experimental sea urchins did not ensure normal embryo development. Even though during the process of fertilization we used only defined cells 
from individuals subjected to long-term hydrocarbon exposure (2nd and 3rd experimental variants), we could observe many abnormalities at all stages of embryogenesis. Fertilization of experimental eggs with experimental sperm in the fourth variant resulted in abnormal, non-viable plutei; thereafter, the larvae ceased to develop.

Table 1. Strongylocentrotus nudus. Long-term effects of light diesel fuel hydrocarbons (30 \pm $5 \mathrm{mg} \mathrm{l}^{-1}$ ) on fertilization. $\mathrm{I}=$ gametes of controls,$\Pi=$ eggs of controls and sperm of experimentals, $\mathrm{III}=$ eggs of experimentals and sperm of controls, $\mathrm{IV}=$ gametes of experimentals

\begin{tabular}{|ccccc|}
\hline $\begin{array}{c}\text { Experiment } \\
\text { no. }\end{array}$ & I & \multicolumn{2}{l}{ Fertilized eggs (\%) } \\
II & III & IV \\
\hline $1(1978)$ & 98 & 98 & 93 & 92 \\
$2(1979)$ & 99 & 98 & 90 & 84 \\
\hline
\end{tabular}

Table 2. Strongylocentrotus nudus. Long-term effects of light diesel fuel hydrocarbons (30 \pm $5 \mathrm{mg} \mathrm{l}^{-1}$ ) on the first cleavage (see Table 1)

\begin{tabular}{|ccrrrrrrrrrrrr}
\hline $\begin{array}{c}\text { Experiment } \\
\text { no. }\end{array}$ & \multicolumn{3}{c}{ Double-cell embryos } & \multicolumn{3}{c}{ Undivided eggs } & \multicolumn{3}{c|}{ Abnormal embryos } \\
& I & II & III & IV & I & II & III & IV & I & II & III & IV \\
\hline $1(1978)$ & 95 & 74 & 75 & 49 & 2 & 6 & 11 & 13 & 3 & 20 & 14 & 38 \\
$2(1979)$ & 90 & 84 & 59 & 56 & 2 & 5 & 8 & 9 & 8 & 11 & 33 & 35 \\
\hline
\end{tabular}

The effect of hydrocarbons on fertilization was the least prominent. As can be seen from Table 1, the proportion of fertilized eggs in all variants of the first and second experiments (except Variant 4 of the 2 nd experiment) exceeded $90 \%$. Table 2 demonstrates long-term effects of light diesel fuel hydrocarbons on egg cleavage. The number of normal double cell embryos in experiments with gametes from experimental sea urchins was 20 to $40 \%$ lower than in experiments with sex cells from controls. These findings are in agreement with those of Allen (1971) who investigated the effects of several kinds of oil products on the early embryogenesis of Strongylocentrotus purpuratus. Allen concluded that sea urchins are most sensitive during cleavage. Lönning \& Hagström (1975) also reported a slight inhibiting effect of oil products on sea-urchin fertilization.

We observed the most successful gastrulation in experiments with gametes of controls. After $20 \mathrm{~h}$ the embryos were at the stage of late gastrula, with well formed guts. Gastrulae are mobile, and inhabit the water's surface layer. In the 2nd and 3rd variants there were fewer actively swimming gastrulae; many lay motionless on the bottom of the dishes. The results of Variant 4 were very different from those of the previous experiments. A small number of swimming gastrulae at early and middle stages of development, as well as distinctly abnormal forms, were observed.

After $48 \mathrm{~h}$ the first experimental variant produced normal, actively swimming fourarm plutei. Variants 2 and 3 led to less abundant swimming larvae, and many plutei with shortened arms were observed among the less mobile larvae lying on the bottom of the 
dishes. Plutei of Variant 4 were distinctly abnormal: they were small with shortened arms and a reduced skeleton.

Abnormalities in Variants 2, 3 and 4 at gastrulation and plutei formation were caused by disturbances in differentiation of larval organs. The formation of cells of primary mesenchyma and the process of invagination in embryos from experimental gametes were inhibited, thus inducing the appearance of larvae with reduced skeletons and guts. Similar disturbances were described by Lönning \& Hagström (1975) in the embryogenesis of Psammechinus miliaris and Paracentrotus lividus whose gametes had been previously treated with water-soluble fractions of crude oils. Probably long-term hydrocarbon effects on developing sex cells cause the same embryological disturbances as those which appeared in embryos and gametes after short-term oil exposure.

\section{CONCLUSIONS}

Long-term effects of sublethal hydrocarbon concentrations cause the formation of defective sex cells in Strongylocentrotus nudus. These give rise to non-viable offspring. The physiological basis of the damage requires further investigation. Purified oil products with a high concentration of aromatic hydrocarbons are considered most toxic (Anderson, 1977); diesel fuel used in the present study is of the same category (Anderson, 1977). Histological studies provided no evidence for changes in cells exposed to hydrocarbons. Moreover, according to Lönning \& Hagström (1975), no differences in ultrastructure of sea-urchin embryos could be recorded. Some authors believe that aromatic hydrocarbons, owing to their solubility in lipids, break down the composition of lipoprotein cellular membranes, thus changing their permeability and consequently their cell metabolism (Van Overbeek \& Blondeau, 1954, cited by Nelson-Smith, 1977; Morrow et al., 1975).

\section{LITERATURE CITED}

Allen, H., 1971. Effects of petroleum fractions on the early development of a sea urchin. - Mar. Pollut. Bull. 2, 138-140.

Anderson, I. W., 1977. Effects of petroleum hydrocarbons on the growth of marine organisms. Rapp. P.-v. Réun. Cons. int. Explor. Mer. 171, 157-165.

Evdokimov, V. V., 1973. Experimental regulation of gametogenesis of sea urchins. Abstract of master's thesis. Vladivostok, $27 \mathrm{pp}$.

Lönning, S. \& Hagström, B. E., 1975. The effects of crude oils and the dispersant Corexit 8666 on sea urchin gametes and embryos. - Norw. J. Zool. 23, 121-129.

Moore, S. F. \& Dwyert, R. L., 1974. Effects of oil on marine organisms: a critical assessment of published data. - Wat. Res. 8, 819-827.

Morrow, J. E., Gritz, R. L. \& Kirton, M. P., 1975. Effects of some components of crude oil on young Coho salmon. - Copeia 2, 326-332.

Nelson-Smith,A., 1972. Oil pollution and marine ecology. Elek, London, $302 \mathrm{pp}$.

North, W. J., Neushul, M. \& Clendenning, K. A., 1965. Successive biological changes observed in a marine cove exposed to a large spillage of oil. - Symp. Commn int. Explor. scient. Mer Médit., Monaco 1965, 335-354.

Payne, J. F, Kicenjuk, J. W., Squires, W. R. \& Fletcher, G. L., 1978. Pathological changes in a marine fish after a 6-month exposure to petroleum. - J. Fish. Res. Bd Can. 35, 665-667.

Reynard, S., 1973. Reproductive potential of limpets near a refinery effluent in Milford Haven. Field Studies Council Oil Pollution Research Unit Orielton Field Centre, Pembroke, 44-46.

Straughan, D., 1976. Sublethal effects of natural chronic exposure to petroleum in the marine environment. - The American Institute Environmental Affairs Department, $119 \mathrm{pp}$. 